SAAVEDRA, M.: 'Percursos da vacina na Índia portuguesa - séculos XIX e XX'. História, Ciências, Saúde-Manguinhos, vol. 11 (suplemento 1): 165-82, 2004.

Percursos da vacina na Índia portuguesa séculos XIX e XX*

\section{The pathways of the vaccine in nineteenth} and twentieth-century Portuguese India Portu

Este artigo é um dos resultados do projeto "Medicina Tropical e Administração Colonial: um Estudo do Império a Partir da Escola Médica de Goa", coordenado por Cristiana Bastos no Instituto de Ciências Sociais da Universidade de Lisboa (ICS), e subsidiado pela Fundação para a Ciência e a Tecnologia entre 2001 e 2003. Também é fruto do projeto "Medicina Colonial, Estruturas do Império e Vidas Pós-Coloniais em Português", desenvolvido no ICS e financiado pela FCT, no âmbito do "Programa Operacional Ciência, Tecnologia, Inovação", integrado no Quadro Comunitário de Apoio III, com a participação FEDER. A pesquisa conta com apoio de IICTI (GRICES) CNPq.

\section{Mónica Saavedra}

Investigadora do Instituto de Ciências Sociais da Universidade de Lisboa

Av. Prof. Aníbal de Bettencourt, 9, 1600 - 189

Lisboa, Portugal

msaa@clix.pt
Neste artigo procura-se refletir sobre as vicissitudes da integração da vacina antivariólica na sociedade goesa (Estado da Índia Portuguesa) do século XIX. A prática da vacinação antivariólica - em confronto com a inoculação variólica - põe a descoberto dinâmicas sociais locais e redes de relações de poder que não se esgotam na dualidade colonizador/colonizado, combinandose com as questões científicas e técnicas importadas da Europa e apropriadas localmente. Os documentos oficiais, produzidos pelos médicos do serviço de saúde e outras autoridades administrativas, revelam os atores implicados na sorte da vacina antivariólica, suscitando hipóteses interpretativas sobre suas motivações relacionadas a fatores (sociais, econômicos, técnicos, políticos) que condicionavam seu discurso e sua ação.

PALAVRAS-CHAVE: vacina, variolização, Goa, medicina colonial, história da medicina.

SAAVEDRA, M.: 'The pathways of the vaccine in nineteenth and twentieth-century Portuguese India'.

História, Ciências, Saúde-Manguinhos, vol. 11 (supplement 1): 165-82, 2004.

The article explores the vicissitudes of the nineteenth-century introduction of the smallpox vaccine into Portugal's Indian colony of Goa. The choice to use smallpox vaccines instead of inoculation evinces local social dynamics and power networks that cannot be reduced to a colonizer-colonized duality but that interact with scientific issues and techniques imported from Europe and adopted locally. Official documents issued by bealthservice physicians and other administrative authorities reveal the actors involved in the fate of the smallpox vaccine, raising bypotheses about the motives (involving social, economic, technical, and political factors) that shaped their discourse and actions.

KEYWORDS: vaccine, variolização, Goa colonial medicine, bistory of medicine. 
${ }^{1}$ A variolização consistia na inoculação de indivíduos sãos com varíola humana, no intuito de provocar uma manifestação moderada e controlada da varíola, tornando os inoculados imunes à doença; era praticada na Ásia havia séculos

e provavelmente era também conhecida em África.

\section{Introdução}

A vacina antivariólica foi oficialmente trazida ao conhecimento do A público científico no final do século XVIII, pela mão do cirurgião britânico Edward Jenner. Mais do que uma descoberta ou revolução científica, a vacina era, em termos técnicos e no seu efeito profilático, uma espécie de continuidade da variolização. ${ }^{1}$ A inoculação de varíola humana começara a ser praticada medicamente na Europa a partir do início do século XVIII. Quanto à vacina, ela tinha a mesma finalidade profilática e usava o mesmo princípio da inoculação variólica, mas com matéria da varíola bovina (cowpox). Esse princípio imunizante da varíola bovina já havia sido notado nas comunidades rurais que lidavam com bovinos; por conseguinte, não seria de estranhar que nessas comunidades se tivesse algumas vezes praticado a inoculação com matéria retirada das vacas, antes dos trabalhos de Jenner (Baxby, 1996; Grmek, 1996). Mas a apropriação médica da vacina e as subseqüentes tentativas para sua vulgarização acabaram por conferir-lhe outras conotações e submetê-la ao julgamento de um número crescente de indivíduos, desencadeando desconfianças, debates e disputas.

À complexidade do enquadramento científico e sociopolítico, bem como à diversidade de significados que rodeavam a vacina na Europa deve-se acrescentar a diversidade sociocultural com a qual é progressivamente confrontada, resultado das redes políticas, econômicas e científicas que ligavam a Europa ao resto do mundo, dilatadas pela expansão colonial do século XIX.

É um truísmo dizer que a vacina não mereceu o reconhecimento universal na Europa, mesmo dentro da comunidade médica. Mas no caso dos contextos coloniais de África e da Ásia, a recepção e a resposta à introdução e regulamentação daquele método profilático merecem ainda outras reflexões, a respeito de seu significado e alcance na dinâmica das relações de poder.

Seguindo a produção historiográfica sobre a participação da medicina na expansão e no exercício do poder colonial europeu (entre outros, os trabalhos de MacLeod et al., 1988; Manderson, 1996, mas principalmente o de Arnold, 1993, sobre a complexidade da prática da vacina na Índia britânica), pretendo mostrar como a vacina antivariólica em Goa assume particularidades que se acrescentam ao debate sobre a relação entre medicina e poder colonial (ver mapa à p. 14).

Arnold analisa múltiplos fatores culturais, sociais, políticos e financeiros que marcaram a integração da vacina na Índia britânica; dá algum realce à variolização e às representações da varíola entre a população indiana, referindo-se ao modo como a administração colonial inglesa geriu as reações à vacina em face dessas práticas e representações. Neste artigo, irei me referir igualmente à variolização em Goa, procurando perceber o que estava realmente em causa no 
${ }^{2}$ Uso a designação Estado da Índia quando me refiro a dados históricos ou da administração da saúde relativos à colônia. Uso a designação Goa quando analiso dados concretos da vacina e variolização, uma vez que me baseio essencialmente em documentos referentes a essa parte do Estado da Índia. confronto entre a vacina e a variolização. Darei ainda conta dos atores em interação e das suas motivações e condicionalismos.

Apesar desses paralelismos entre as "duas Índias" (britânica e portuguesa), existiam condições díspares que é necessário levar em conta como contexto de referência. Enquanto, ao longo do século XIX, a Índia britânica cresceu em importância para o colonialismo britânico, Goa conheceu, no mesmo século, problemas graves decorrentes da conturbada situação política da metrópole (sobretudo na primeira metade do século XIX) e de sua própria decadência dentro do 'mundo português'. Constituído por Goa, Damão e Diu, territórios descontínuos na costa oeste da península indiana, o Estado da Índia ${ }^{2}$ fora, como a Índia britânica para o Reino Unido, a jóia da coroa portuguesa. Mas com a crescente importância do ouro do Brasil na economia nacional, o Estado da Índia entrou em declínio a partir do século XVIII. No século XIX, e apesar da independência do Brasil, sua importância para o 'império' português era sobretudo simbólica. Ela estava presente em todos os discursos de exaltação das glórias dos navegadores portugueses e nas narrativas sobre a construção do império no oriente, essa região mítica.

Por conseguinte, em relação àquele território Portugal não tinha qualquer projeto de colonização; limitava-se tão-somente a administrálo - e, a julgar por alguns dos relatos médicos em Goa, com o menor dispêndio e esforço possíveis - contando para isso com a participação de uma elite local.

Nesse cenário, partir do pressuposto da existência de um projeto colonial português envolvendo a medicina e os médicos pode iludir o olhar sobre as questões levantadas pelas tentativas de integrar a vacina na sociedade goesa; entre outros motivos, porque poderia relegar para um plano secundário a ação e reação dos atores locais, bem como a questão das relações locais de poder.

No contexto goês, tal como no europeu, a vacina não pode ser percebida como um fenômeno exclusivamente científico, médico e institucional. Anne-Marie Moulin (1996a, p. 12) faz notar que "a lei científica da imunização exige uma outra lei no seu reverso, que a projeta no espaço social, e a aventura da vacinação não existiria sem uma validação política”. Ela remete-se ao conceito de 'vacinologia', forjado por Jonas Salk e definido como a pesquisa e aplicação dos elementos necessários a uma vacinação eficaz. Nesses elementos, Salk incluía a interligação de fatores "antropológicos, econômicos, culturais, éticos, políticos e científicos" (idem, ibidem, pp. 12-3).

Esses elementos congregavam-se em uma rede de atores e interações que deveriam constituir a sustentação da vacina. Mas, na verdade, a rede de relações hierarquizadas revelava-se vulnerável e esparsa (Latour, 1993), fragilidades tanto mais evidentes quanto mais agentes ela tentava envolver e quanto mais procurava expandir-se. Mais do que uma rede 
de discursos ou modelos abstratos, a vacina implica prática, e na prática buscava os seus principais elementos de sustentação, procurando compensar a fragilidade do discurso científico que a envolvia. Mas era justamente no plano da prática que as maiores debilidades dessa rede se tornavam visíveis. Nela se condensavam tensões e conflitos que ultrapassavam a estrita dimensão médica da vacina. O que estava em causa era o seu significado e o modo como se apresentava à população (Arnold, op. cit.).

\section{A vacina e a medicina européia no espaço colonial}

A vacina antivariólica foi, no século XIX, um exemplo privilegiado de "empirismo científico" (Grmek, op. cit.), mas também um signo sujeito a diversos significados e apropriações.

A fluidez de significado, manifestada na diferença entre discurso, regulamentação e prática, escapando aos rigores do laboratório bacteriológico que se afirmaram e adensaram depois de 1880 (Worboys, 2000), torna a vacina e a vacinação um campo expressivo de processos e dinâmicas sociais inscritos nas práticas da administração da saúde, dentro e fora da Europa.

Os médicos e cirurgiões praticando fora do continente europeu tiveram, durante algum tempo, por especial objeto da sua ação os administradores e militares sediados nas colônias, marcando território, guardando e dilatando fronteiras. Mas ao longo do século XIX o novo rumo do colonialismo europeu veio a refletir-se também no discurso e nas práticas da medicina; estes descentram-se dos europeus para se alargarem sistematicamente em direção às populações nativas que os rodeavam, resultando em confrontos com repercussões no exercício do poder colonial e sua recepção pelas populações colonizadas, bem como na ciência e prática médicas.

$\mathrm{Na}$ Europa, durante as últimas décadas do século XIX, as diversas investigações sobre a natureza e o papel dos germes permitiam a identificação dos agentes causadores das infecções e ofereciam ainda uma explicação sobre o modo como esses agentes se transmitiam das pessoas infectadas para as sãs. Crescia a importância do controle dos indivíduos e seus hábitos, e não apenas do controle das condições do meio físico mais amplo (idem, ibidem). O corpo e o indivíduo ocupavam assim, definitivamente, um lugar central na saúde pública.

Entretanto, a vacina contava com praticamente um século de existência e resistira aos debates sobre contagionismo e infeccionismo, sanitarismo e quarentenismo. Resistira mesmo aos permanentes debates sobre a relação entre a varíola e a vacina e à pouca clareza que sempre envolvera os argumentos usados para explicar essa relação. Sobrevivera e afirmara-se, apesar do problema das infecções propagadas pela vacinação e dos constantes episódios de vacinação 
ineficaz; resolvera ainda o problema da impossibilidade de se garantir imunidade vitalícia com uma vacinação.

Todas essas incertezas e desaires não impediram a vacina de ganhar terreno e de enquadrar-se perfeitamente na reorientação das respostas médicas às questões da saúde, então ancoradas nos germes como causadores de doenças e nas possibilidades oferecidas pelos laboratórios para reconhecê-los e, assim, supostamente, controlálos. Na verdade, a inoculação teve mesmo um papel de relevo nas investigações bacteriológicas, e a vacina adquiriu protagonismo e foros de 'modelo real' das investigações pasteurianas, pois Pasteur reconhecia nela o princípio implícito da atenuação dos germes (Moulin, 1996b).

Olhemos agora para a afetação mútua entre a percepção dos territórios e populações das colônias européias, por um lado, e o desenvolvimento e consolidação da bacteriologia, por outro. A bacteriologia encontrou terreno para o seu desenvolvimento e para o reforço do seu papel social, econômico e político nos territórios coloniais - férteis de doenças percebidas e experimentadas como obstáculos à exploração e à colonização plenas. Vários laboratórios foram criados em diversas colônias européias, e diversos institutos semelhantes ao Instituto Pasteur de Paris instalaram-se em territórios coloniais. As pesquisas sobre o paludismo e sobre a peste bubônica foram marcos das investigações bacteriológicas em medicina tropical.

Mas os efeitos da bacteriologia nas estratégias de saúde das colônias não se resumem às investigações da medicina tropical. Ao colocarem o enfoque no corpo e nos hábitos dos indivíduos para explicar a transmissão dos germes e a forma de a prevenir, a bacteriologia reforçava o olhar e o discurso diferenciadores sobre as populações nativas das colônias européias. Assim, não era só o meio que representava uma adversidade à fixação dos europeus e ao desenvolvimento das populações locais; eram também os costumes, a 'superstição', os 'hábitos retrógrados e irracionais' arraigados nessas populações. Era necessário salvá-las do 'obscurantismo' e da 'degenerescência' aos quais estavam condenados pela sua própria conduta e 'menoridade mental'.

Nesse contexto, o papel da vacina reforçava-se potencialmente: por um lado, era o modelo real das investigações pasteurianas; por outro, desde sempre implicava uma intervenção direta sobre as pessoas, deslocando as 'defesas' contra as epidemias do meio para o corpo. Mais uma vez a vacina aproximava-se dos discursos de superioridade dos modelos europeus ditos racionais, por contraste com modelos e organização sociais e culturais dos nativos das colônias.

Se a bacteriologia ajudou a sancionar cientificamente um certo discurso sobre a diferenciação dos grupos humanos, com base na classificação dos seus comportamentos e hábitos, na verdade a percepção 
dessas diferenças esteve sempre presente nos discursos médicos coloniais ao longo do século XIX. Em Goa, a insistência nas diferenças culturais experimentadas e observadas dominava os relatos dos médicos da metrópole e dos médicos goeses sobre as repostas sociais à vacinação, sobre o modo de perceber a varíola e de responder a ela. Dentre essas diferenças, a constante referência à inoculação da varíola humana, praticada pelas populações locais, assumiu um caráter simbólico de expressão de distinções — religiosa, civilizacional, social.

É inegável que o discurso e as percepções dos médicos europeus sobre as doenças nas colônias assentavam-se sobre impressões fortes, inspiradas pela experiência cotidiana de condições materiais, climáticas e socioculturais muito diversas das da metrópole e pela dificuldade em perceber a lógica das representações da doença entre as populações nativas. Essas impressões explicam, em certa medida, a intensidade dos discursos sobre as 'superstições' locais, impeditivas dos avanços civilizacionais da medicina européia, concretamente por meio da vacina. Mas a própria necessidade de afirmação dos médicos perante as autoridades coloniais, bem como sua necessidade de criar e assegurar um domínio de especialização, de adquirir prestígio e estatuto para a classe médica nos territórios coloniais terão também contribuído para alimentar esse discurso, um pouco à semelhança do que sucedera na metrópole.

Contudo, em Goa, muitos dos médicos eram nativos; por isso, a questão da estranheza cultural seria relativa, apesar das diferenças entre as elites cristianizadas e os grupos sociais hindus, ou entre classes sociais diversas. Assim, devemos perceber a adoção de discursos diferenciadores, hierarquizantes e pejorativos, baseados nos princípios da 'medicina racional', em confluência com condicionalismos sociais decorrentes da ordem local e das relações de poder nela implícitas. A vacina, como outras intervenções médicas, entra em uma gestão complexa de relações que não se esgotam nas questões do exercício do poder colonial.

\section{Vacina versus variolização em Goa}

Centremo-nos, então, na história da vacina em Goa, na titubeante negociação e construção de uma ordem convergente de modelos e conexões que permitisse cumprir o projeto de universalização do profilático da varíola; vejamos ainda os decorrentes significados sociais que tal objetivo teria para a ciência e a prática médicas naquele território, bem como para os sujeitos voluntária ou involuntariamente implicados nessas relações.

A vacina jenneriana chegou a Goa provavelmente em 1802, a julgar por um documento publicado no Archivo de Pharmacia e Sciencias Accessorias da India, de 1865. Esse documento, assinado pelo físico-mor António José de Miranda e Almeida e datado de 1805, 
relata inoculações com vacina feitas havia mais de três anos. As vacinações efetuadas pelo físico-mor foram iniciadas com matéria enviada ao governador-geral Francisco António da Veiga Cabral pela Companhia Britânica, que então detinha a concessão do comércio na Índia inglesa, administrando-a.

As informações dadas pelo físico-mor eram bastante otimistas: dizia que, apesar dos "prejuízos, que grassam nos nativos deste país, os sucessos sempre felizes, e a facilidade com que esta operação se pratica, tem convencido e sujeitado a maior parte a inocular-se" (Almeida, 1805, p. 23).

Mas outros relatos médicos, menos otimistas e mais indignados, surgiram ainda na primeira metade do século XIX, dando conta de divergências entre as autoridades ligadas ao serviço de saúde e a população local. Os costumes e hábitos cotidianos da população, bem como os princípios religiosos que os médicos entendiam estarlhes associados tornavam-se referências freqüentes e quase sempre carregadas de juízos e conotações pouco abonatórias. Esses comentários eram feitos a propósito da resistência - quase sempre passiva - à vacinação, mas também de outras intervenções ditadas pelos princípios da saúde pública e da ciência sanitária.

Em todos os documentos oficiais emanados do Serviço de Saúde do Estado da Índia ao longo do século XIX, e em vários outros produzidos nas primeiras décadas do século XX, sempre que se menciona a vacina surgem também referências à variolização. Em conseqüência, para refletir sobre as dinâmicas sociopolíticas manifestadas nos discursos e na prática da vacinação, é impossível ignorar esse outro método profilático como símbolo com várias conotações e significados, em aparente disputa com a vacina.

$\mathrm{Na}$ falta de dados quantitativos sobre a prática da variolização em Goa, torna-se difícil avaliar até que ponto ela constituía uma alternativa concorrente da vacina. Contudo, parece haver consenso quanto ao fato de se tratar de um recurso profilático conhecido e procurado por indivíduos de todas as religiões, em várias regiões da península indiana (Jaggi, 1980; Arnold, op. cit.). Resta saber se os médicos superestimavam ou não a prática da variolização para marcar outras diferenças e fronteiras (profissionais, sociais etc.).

Nas diferentes regiões da Índia onde era praticada, a variolização estava associada a um culto popular com rituais diversos (Jaggi, op. cit.), relacionado com a varíola e centrado em uma divindade feminina. Segundo os relatos dos médicos, esse culto também era conhecido em Goa:

\footnotetext{
3 Devi significa 'deusa' (Almeida, 1912) e é outra designação para Sitala.
}

Para a massa do povo e em especial para a classe hindu, a varíola representa uma divindade ou encarnação de uma deusa a que dão o nome de Devi. ${ }^{3}$ Não obstante reconhecerem como doença contagiosa e mortífera, não a temem, nem se arredam dela: - pelo contrario vão adorá-la, oferecer-lhe flores, como deusa amorável 
que visita os seus devotos uma vez na vida. E daí a sua ilimitada confiança que toca as raias de obsessão, pela inoculação de vírus variólico de preferência à vacina jenneriana que entre eles não chegou ainda nem chegará tão cedo, a deitar raízes como processo imunizante (Dias, 1902).

A varíola era interpretada como uma manifestação da deusa e desencadeava em torno dos afetados e seus próximos um conjunto de rituais com a dupla função de prestar homenagem e apaziguar a divindade (Arnold, op. cit.).

A variolização não era uma forma de evitar a varíola, mas sim de garantir que a deusa não se manifestaria violenta e aleatoriamente. Aqui residia uma das principais dissonâncias entre as intervenções médicas da administração colonial e as práticas locais relacionadas com a varíola. Impedir a manifestação da doença era inconcebível para os modelos indianos, pois implicava interferir com a esfera do divino. Por outro lado, a variolização reproduzia uma concepção da ordem social e harmonia nos indivíduos — harmonia percebida como equilíbrio orgânico, mas também como equilíbrio na relação com o meio a que pertenciam, onde criavam e faziam sentido. Arnold (op. cit.), na sua abordagem das dificuldades da vacinação na Índia britânica, menciona ainda que a vacina antivariólica colocava problemas graves no tocante à hierarquia e às relações de evitamento entre as castas, uma vez que a proveniência da matéria vacínica utilizada era duvidosa e que o contato com os próprios vacinadores podia violar as regras de evitamento físico entre sexos e castas.

O argumento 'castista' como entrave à vacinação aparece enunciado nos relatórios dos médicos em Goa, embora não exaustivamente explorado. Contudo, a questão das castas era tão premente na sociedade goesa como na Índia britânica, surgindo nas páginas dos jornais de Goa ao longo do século XIX e ainda na primeira metade do século XX. A diferenciação entre castas podia não ser evidente, mas emergia em alguns momentos de forma muito clara por trás de interesses e disputas de influência e poder. Assim, não seria de estranhar se razões de casta fossem também convocadas para justificar a recusa da vacina, tais como o eram os argumentos religiosos.

Tudo o que foi dito sobre a variolização não pretende caracterizála como um fato cultural centenário, estável e imutável. Como culto e prática populares, a veneração de Sitala/Devi e a variolização são facilmente transmutáveis e apropriáveis pelos indivíduos de diversas religiões, conforme a sua experiência, motivação e propósito. Por contraste, a vacinação demorava a encontrar a mesma maleabilidade e multiplicidade de sentidos, bem como a ser apropriada e despojada de conotações sem significado para o contexto goês. Era necessário 'traduzi-la' para que integrasse uma lógica próxima daquela que tinham a varíola e a variolização (Almeida, 1858; Ribeiro, 1917). A vacina limitava 
a participação dos receptores; deles esperavam-se apenas aquiescência e passividade. Além disso, os vacinadores eram quase sempre indivíduos sem qualquer ligação com o grupo; tratava-se da intromissão de um estranho nas rotinas do equilîbrio comunitário, o que reforçava as assimetrias na relação entre os sujeitos em interação.

Anne-Marie Moulin (1996a) reconhece, na persistência da variolização em algumas colônias européias, uma forma de resistência à autoridade colonial. Essa possibilidade não deve ser excluída, para o caso de Goa, porém ressalvando-se que a resistência não pode ser percebida como um movimento organizado, projetado e intencional de reação política à repressão ou dominação colonial. A resistência resultava provavelmente desse confronto entre significados e representações dissemelhantes entre indivíduos, entre grupos sociais. A relação concreta e localizada entre o vacinador e os indivíduos que ele tinha por missão vacinar acionava uma série de fatores (língua, raça, classe, religião, estatuto social etc.) com peso no resultado dessa interação e não redutíveis à dicotomia colonizador/colonizado. Em suma, a resistência à vacina pode ser interpretada como uma metáfora das muitas incompatibilidades em jogo. Tendo essas considerações em mente, é também nessa perspectiva que, em parte, devemos procurar perceber o porquê da insistência dos médicos em reprimir a variolização.

A variolização era repetidamente mencionada nos diplomas legislativos pelo menos até os anos 1930. O diploma legislativo provincial no 261, de 17 de março de 1927, estabelecia novas bases para o serviço de vacinação antivariólica e determinava, no art. 5o, que era "expressamente proibida a inoculação variólica". As tentativas para dominar a variolização superaram as de tornar a vacina obrigatória; mas ambas se repetiram ao longo do século XIX e ainda no século XX, sem que fossem rigorosamente observadas.

Entre os médicos europeus e goenses não havia unanimidade quanto à atitude a adotar em relação à variolização ou à resistência passiva da população. Na primeira metade do século XIX, as posições dos médicos naturais da metrópole eram em geral de intransigência:

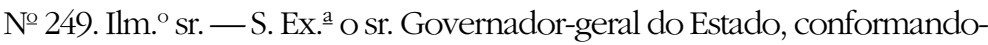
se inteiramente com os sólidos fundamentos do ofício n⿳ำ 6 , da data de 16 do corrente mês, do Conselho de Saúde Publica, a que V. S. ${ }^{\underline{a}}$ preside, que cobria e informava o requerimento da Comunidade e Habitantes da Aldeia Cassabé da Província de Bicholim, os quais aferrados por fatal cegueira aos seus antigos costumes, rejeitam a utilíssima instituição da vacina, e pretendem se lhes permita o uso da inoculação; indeferido o mesmo requerimento, mandando cumprir literalmente o despacho do ex-vice-rei o sr. dom Manoel de Portugal e Castro, de 13 de maio de 1830, que deu a este respeito a mais salutar providência a bem daqueles povos: o que o mesmo Exm. ${ }^{\circ}$ Sr. quer que eu tenha a honra de participar a V. S. $\underline{a}$, e de lhe dizer ao mesmo tempo, que S. Ex. ․ㅗ se 
achava tão convencido dos princípios que estabelece o referido Conselho, sobre tal assumpto, que já em data e 24 de fevereiro último proibiu, sob rigorosas penas, a inoculação da Aldeia de Siolim da Comarca de Bardez, onde alguns charlatães pretendem introduzir semelhante flagelo (Garcez, 1844, p. 3).

Mas surgiam também algumas hesitações em condenar radicalmente a inoculação com varíola:

O que estava e está ainda em grande crédito é a inoculação do vérus variólico, que inoculadores lá dos Gates empregam como preservativo, temperado de diversos modos, mas ordinariamente com leite, o que produz algumas pústulas e febre, sem mais acidente algum; de modo que se se não receasse o desenvolvimento de epidemia que aliás talvez não teria lugar, tais inoculadores poderão ser tolerados (Oliveira, 1853).

Na verdade, a passagem do discurso médico à ação, quando surgiam conflitos desencadeados pela vacina, ou quando se tratava de reprimir a variolização, dependia também da mediação das autoridades administrativas. Estas eram algumas vezes apontadas como 'forças de bloqueio' à ação dos médicos:

Continua a luta da Junta de Saúde, dos seus delegados, e do governo, para obstar à inoculação das bexigas naturais, mas forçoso é confessarse, como os nossos delegados, e os do governo são, pela maior parte, os primeiros partidários da inoculação, os nossos esforços são quase sempre burlados, e mui poucas vezes são cumpridas à risca as nossas determinações (Almeida, 1858).

No plano da administração local (concelhia ou das comunidades), havia a considerar o peso das relações sociais e das hierarquias, sujeitas a regras que ultrapassavam o nível da organização e da estrutura administrativas coloniais. O equilíbrio e a manutenção da autoridade local — esta quase sempre exercida por naturais de Goa, mais dependentes das redes sociais locais - podiam ser comprometidos se os administradores insistissem no estrito cumprimento de regras emanadas da autoridade colonial, baseada em princípios, modelos e ideologia estranhos à maioria da população. Daqui se depreende o papel determinante das elites locais como 'co-gestores' do poder colonial.

O mesmo tipo de constrangimentos sociais podia aplicar-se aos médicos goenses. Por seu pertencimento ao meio social em que atuavam e pela dependência em relação a ele, cada ação requeria maior avaliação de riscos, envolvendo um exercício de gestão do prestígio social junto à autoridade colonial, por um lado, e junto ao grupo social a que pertenciam, por outro.

Ao avançarmos no século XIX, encontramos sinais da ambigüidade na forma de responder à persistência da inoculação variólica; ou da 
impossibilidade de a superar; ou ainda de tolerância para com essa prática, sobretudo nas estatísticas elaboradas pelo chefe do Serviço de Saúde do Estado da Índia, João Stuart da Fonseca Torrie, durante a década de 1870. Nelas surgem registrados números consideráveis de militares goenses inoculados com varíola:

\begin{tabular}{|c|c|c|c|c|c|c|}
\hline $\begin{array}{l}\text { Profilático de } \\
\text { bexiga }\end{array}$ & $\begin{array}{l}\text { 1. batalhão } \\
\text { do regimento } \\
\text { de infantaria } \\
\text { do ultramar }\end{array}$ & $\begin{array}{c}\text { Corpo de } \\
\text { polícia }\end{array}$ & $\begin{array}{l}\text { Companhia de } \\
\text { saúde }\end{array}$ & $\begin{array}{c}\text { Corpo de } \\
\text { fiscalização }\end{array}$ & $\begin{array}{c}\text { Companhia de } \\
\text { reformados }\end{array}$ & Total \\
\hline Inoculados & - & 321 & 4 & 106 & - & 431 \\
\hline Não consta & 1 & 12 & 24 & 13 & 49 & 99 \\
\hline Tiveram bexigas & 15 & 272 & 10 & 99 & 207 & 603 \\
\hline Não vacinados & 16 & 14 & - & - & - & 30 \\
\hline Vacinados & 275 & 259 & 1 & 89 & - & 624 \\
\hline Soma & 307 & 878 & 39 & 307 & 256 & 1787 \\
\hline
\end{tabular}

Fonte: João Stuart da Fonseca Torrie (1883).

Já no século XX, quando a especialização técnica da vacina e as preocupações com a assepsia poderiam somar argumentos contra a variolização, esta ainda era pontualmente considerada um mal menor (Dias, op. cit.), não só em face da resistência à vacinação, mas também pelas dificuldades da administração colonial em corresponder às exigências técnicas da vacinação generalizada. Contudo, os médicos goenses não deixavam também de discursar contra a variolização, apontando-a como origem de muitos surtos no território goês. Veja-se como Froilano de Melo (1917, p. 6), um prestigiado médico de Goa, expõe o efeito perverso da variolização, enquadrando-a no modelo pasteuriano:

À proporção, porém, que as inoculações vão aumentando em serie, desenvolvem-se verdadeiras epidemias mortais que não ficam a dever coisa alguma em gravidade e perigo às infecções em que a virulência dos agentes foi exaltada por passagens seriadas em animais sensíveis.

Repetem-se também os relatos de resistência à vacina, geralmente explicada, tal como a preferência pela variolização, pela ignorância e superstição do povo, quase sempre associadas à religião hindu:

... não podendo conseguir realizar a desinfecção de causas e efeitos nem o isolamento dos atacados, visto o público bastante supersticioso, ignorante e teimoso, não querer de forma alguma cumprir os preceitos de higiene, preferindo, pelo contrário, entrar em casa dos variolosos, com crianças ao colo com propósito deliberado de expô- 
${ }^{4}$ Em 1885, António Rafael Pereira foi o primeiro goês a assumir o cargo de chefe do Serviço de Saúde da Índia portuguesa. Desde essa data e até à independência de Goa, em 1961, o Serviço foi sempre chefiado por médicos naturais de Goa. las ao contágio da doença, pensou no meio profiláctico de vacinação geral. Ao princípio encontrou enormes dificuldades por parte do povo que procurava esquivar-se à vacina (Loundó, 1917, p. 271).

Só por si, portanto, a vacina resolveria todo o problema da profilaxia contra a varíola. Mas, desgraçadamente, este principio salutar ainda não entrou em todos os espíritos, daí essas medonhas catástrofes que ainda se observam, pois a varíola não respeita, como tantas outras doenças, nem a idade, nem o sexo, nem a hierarquia social.

$\mathrm{Na}$ Índia vem ainda agravar este ponto da profilaxia o preconceito religioso dos hindus que acreditam na ação divina da mais mortífera e mais asquerosa doença que ataca larga e facilmente a humanidade (Silva, 1916, p. 102).

Não existe um padrão para as transformações no discurso dos médicos sobre a resistência à vacina, ao longo do tempo. Quer naturais da metrópole, que chefiaram o serviço de saúde até 1885, quer goenses, os médicos oscilavam entre uma postura intransigente e a tolerância ou negociação.

Os boletins dos delegados de saúde na segunda década do século XX são particularmente ilustrativos desse equilíbrio improvisado caso a caso, conforme os atores e circunstâncias em causa (Loundó, op. cit.; Meneses, 1917; Melo, op. cit.). Mas é apenas quando o serviço médico se 'indianiza' e quando, já no século XX, os hindus começam também a ocupar cargos no serviço de saúde, que se insiste na necessidade de desenvolver estratégias suasórias, como o recurso a vacinadores hindus, mais facilmente aceitos pelas populações aldeãs, que professavam o hinduísmo.

Em vista da experiência já feita, é meu parecer que sob responsabilidade do Instituto podem ser nomeados vacinadores hindus não-médicos, quando mereçam toda a confiança do diretor daquele estabelecimento. Estes vacinadores exerceriam a sua ação especialmente nas Novas Conquistas e nas Velhas, mais particularmente entre os habitantes das classes não cristãs (Melo, op. cit., p. 11).

São duas as condições que concorrem para o signatário poder chegar a vacinar um tão avultado número de indivíduos: pertencer ele à classe do povo que sistematicamente se opõe a submeter-se à profilaxia antivariólica, sobretudo quando ela é levada por pessoa de classe diferente da sua; e ter dado a linfa vacínica magnífico resultado criando assim confiança no público (Loundó, op. cit. p. 271).

No entanto, a contemporização coexistia com o recurso à coação, usando as milícias e cercando as aldeias para forçar os habitantes à vacinação ou tentando impedi-los de fazerem inoculações com varíola humana (Melo, op. cit.; Meneses, op. cit.; Santana, 1918).

Embora as questões 'étnicas' e religiosas fossem as mais exploradas pelos médicos metropolitanos e goenses para explicar os reveses da 
${ }^{5}$ Por aquela altura, desenvolveu-se em Goa uma epidemia de varíola, e os jornais publicaram pequenos artigos interpelando o Serviço de Saúde sobre as medidas tomadas para o controle da epidemia, questionando e criticando a demora do serviço em proceder à vacinação (O Ultramar, 1884). Controlados pelas elites cristãs goenses, alguns desses periódicos podiam fazer eco às pressões internas sofridas pelo Serviço de Saúde e contribuir para alimentar os argumentos de Torrie a favor da produção local de vacina animal. vacina antivariólica em Goa, sendo também essas questões as mais visíveis na legislação sobre vacinação, na verdade as divergências e desalinhamentos não se verificavam apenas entre o Serviço de Saúde e a população; estavam também patentes entre o Serviço de Saúde e o governo do território, para além de resultarem de dificuldades técnicas e econômicas.

\section{A vacina animal}

A Goa chegavam os ecos dos debates em torno da vacinação, tendo o universo médico português como intermediário. Em 1868, o farmacêutico António Gomes Roberto (1864-1871) publica, no periódico de farmácia que dirigia em Goa, o discurso feito por um médico francês sobre os problemas levantados pela vacinação braço a braço, as vantagens da vacina animal e a necessidade irrefutável da revacinação. O discurso chegara a Goa por intermédio da Revista de Pharmacia do Porto.

O discurso médico sobre a vantagem da vacina animal - isto é, vacina produzida diretamente em vitelos de onde era recolhida para inocular nas pessoas - chegava a Goa e animava as tentativas para implantar a produção de vacina animal naquele território, na esperança de superar dificuldades na obtenção da matéria usada para a vacinação, mas também na mira de ultrapassar os 'prejuízos castistas' dos hindus contra a vacinação de braço a braço: "A vacina animal, tão elogiada na Europa, é indispensável na Índia, onde os prejuízos religiosos e castistas dos gentios opõem obstáculos quase insuperáveis à vacinação de braço a braço (Torrie, 1884, p. 639). ${ }^{5}$

Sabendo-se que a vacina era produzida induzindo deliberadamente a doença nos animais e submetendo-os a intervenções técnicas para a coleta da matéria, resta saber se a vacina animal teria sido bem recebida pela população hindu - para quem a vaca é um animal sagrado.

Arnold (op. cit.) explica que o raciocínio de que a vacina animal seria acolhida sem problemas na Índia, por ser um produto vindo das vacas, revelou-se completamente errado no território sob administração britânica. Parece evidente que, para a maioria da população hindu, a oposição à vacina como protesto pelo modo de obtenção da matéria não se colocaria, pelo simples fato de que desconheceriam a origem e natureza da linfa usada para a vacinação; logo, a questão religiosa podia parecer complexificação acadêmica. Contudo, um parque vacinogênico não é uma instalação secreta nem discreta; além disso, haveria de contar com a intervenção das elites hindus; estas tinham conhecimento sobre o modo de obtenção da linfa, e a influência dessas elites junto à comunidade hindu não deve ser descurada. Por conseguinte, mais uma vez estaríamos perante uma situação de disputa e mediação de poder, com potencial influência sobre o que poderiam ser as respostas sociais à vacina animal. 
Mas, na verdade, em Goa a vacina animal instala-se definitivamente e com regularidade, apenas já bem adiantado o século XX, não para evitar confronto social mas por constrangimentos orçamentais e técnicos. Por aquela altura, as próprias elites hindus haviam-se apropriado do discurso progressista e civilizacional dos colonizadores e das classes cristianizadas dominantes, o que reduzia o risco de reação social à vacina.

A insistência na produção local de vacina animal em Goa começara a ter maior visibilidade na década de 1880, época em que também na metrópole se estabeleceu o primeiro parque vacinogênico, depois de quase vinte anos de tentativas infrutíferas. Mas, também nessa década, o chefe de saúde Torrie entrou em conflito com o governador Caetano Alexandre de Almeida e Albuquerque, precisamente por causa do serviço de vacinação, com troca de acusações sobre a ineficiência do serviço (Torrie, 1881a, 1881b; Balsemão, 1881).

Entretanto, Goa continuava dependente da Índia britânica mesmo para a obtenção de 'vacina de braço' (Guimarães, 1885a, p. 391). Ainda no século XIX houve, de fato, algumas tentativas para iniciar a produção de vacina animal; a primeira tentativa oficial parece ter acontecido em 1885 (portaria no 310 , de 30 de junho de 1885), mas não foi bemsucedida. No entanto, pelo menos desde 1881, o chefe do Serviço de Saúde João Torrie (1881a, 1881b) tentava persuadir o governo-geral do Estado da Índia da importância de introduzir a vacina animal naquela colônia.

O estabelecimento definitivo do Instituto de Análises e Vacinas aconteceu, por fim, em 1907. Avaliando pelos boletins de saúde dos delegados e do chefe do Serviço de Saúde ao longo das duas primeiras décadas do século XX, o Instituto não contribuiu significativamente para superar a resistência à vacinação com a vacina animal:

... procurei vacinar algumas crianças, sabendo que nestas aldeias de Novas Conquistas há por parte dos habitantes relutância para a vacina, sobretudo em ocasião de epidemias, preferindo-se a velha prática bárbara de inoculação, e que só a vacinação principiada de surpresa faz desman-char. Apesar de todos os esforços empregados pelo signatário e pela autoridade administrativa para se levar avante a vacina, não se pode encontrar senão poucas crianças de gente pobre, tendo todos os outros habitantes feito desaparecer as suas crianças (Meneses, op. cit., p. 434).

Em 1920, o chefe do Serviço de Saúde regozijava-se com a reorganização recente do Instituto, que, até aquela altura, praticamente se limitava a distribuir a vacina obtida na Índia britânica (Silva, 1920).

Os reveses na produção da vacina a partir de bovinos, em Goa, não parecem contudo estar associados a disputas entre adeptos e adversários da vacina animal. As dificuldades de produção local da linfa, em virtude de questões econômicas e talvez do pouco empenho 
administrativo - atendendo ao fato de que havia recursos acessíveis da linfa provenientes da Índia britânica —, podem ser as razões mais difusas e menos personalizadas que explicam a pouca expressividade da questão da produção de vacina animal em Goa nos debates médicos do século XX. No âmbito das questões relacionadas com a saúde pública e o Serviço de Saúde, a vacinação antivariólica continuava a ser mencionada a par de barreiras socioculturais colocadas à sua prática e ao cumprimento das normas estabelecidas.

O problema da conservação era um obstáculo real, e apesar das tentativas levadas a cabo internacionalmente para a implementação de uma vacina seca - a que Froilano de Melo (1930) faz referência -, apenas no início da década de 1950 o mundo conheceu um tipo de vacina realmente resistente ao calor (a vacina obtida por criodessecação, ou seja, dessecação pelo frio), permitindo incrementar consideravelmente o sucesso da vacinação (Fenner, 1996) do ponto de vista técnico.

\section{Considerações finais}

Integrada no corpo de técnicas e saberes médicos europeus transportados para as colônias como parte do aparelho administrativo, a vacina não foi simplesmente transplantada. Para além das transformações dos modelos científicos e técnicos que a enquadravam - e que chegavam à Índia por diversos canais, sujeitos a diversas interpretações e apropriações - , a vacina conheceu transformações e adaptações decorrentes das condições sociais, culturais, políticas e econômicas que encontrava, configurados nas relações entre os agentes envolvidos na sua prática.

Pensar a medicina como elemento de um projeto e prática coloniais em Goa revela-se problemático, em face dos agentes em causa, da lógica das interações em que se envolveram e do modo como as relatavam. A vacina antivariólica é apenas um postigo através do qual podemos perceber a cerrada combinação de condições que subjaz a prática da medicina colonial. Mais do que nas relações entre colonizador e colonizado, é nas dinâmicas internas da sociedade goense que devemos procurar grande parte dos condicionalismos à consolidação de uma rede sólida de legitimação da vacina. Nesse sentido, a história da integração social da vacina em Goa leva-nos a pensar sobre o lugar que ocupavam as elites locais na relação entre medicina e poder colonial.

Na história do percurso da vacina antivariólica nesse cenário colonial em aparente autogestão, para além do debate científico dentro da classe médica prevaleciam o confronto cultural, a gestão e negociação intrincada de estatutos e autoridade e a habilidade de gerir e superar o crescente desinvestimento do Estado em Goa. A vacina, como outras intervenções médicas no Estado da Índia, tinha um efeito catalisador de tensões e conflitos, excitava impressões e reações, alimentava discursos de diferenciação entre europeus e não-europeus e entre grupos sociais 
goenses. O protagonismo por vezes dado à variolização pode ser percebido como expressão da demarcação de diferenças — sem negar a real persistência da inoculação variólica em Goa durante todo o século XIX. A falta de dados sobre a penetração e o alcance dessa prática na sociedade goense a permite-nos apenas conjeturar sobre um possível exacerbamento da sua ocorrência e efeitos, em uma estratégia clássica de reforço de especificidade e superioridade da vacina por reificação do seu oposto.

Um trabalho de maior fôlego, envolvendo o cruzamento de dados etno-históricos referentes à vacinação e à inoculação variólica em Portugal, nas colônias portuguesas de África, no Brasil e em Goa poderia ilustrar com maior clareza a diversidade conjuntural e a negociação da integração social da vacina, como expressão de diferentes experiências do exercício do poder, colonial ou não. Em Cidade Febril, Sidney Chaloub (1996) avança dados e hipóteses interpretativas sobre a relação entre percepções da varíola, prática da variolização e a implantação da vacina no Brasil, atentando para a composição social e as relações hierárquicas e de poder que a caracterizavam. Oferece dados sobre a apropriação discursiva e prática da vacina e da variolização pelos diferentes grupos sociais em confronto, referindo-se à influência e ao significado de práticas mantidas pelos escravos, bem como às tentativas de marcação de fronteiras e estatuto por parte da classe médica.

Essa negociação social em torno da vacina e da variolização ultrapassa o período colonial, ligando-se mais às dinâmicas da sociedade brasileira do século XIX do que à problemática do exercício do poder colonial. Nesse sentido, o trabalho de Chaloub indica possíveis caminhos para uma abordagem comparativa sobre as adaptações e transformações circunstanciais das representações e dos significados da varíola, da variolização e da vacina, segundo os condicionalismos recíprocos entre os agentes em confronto, na lógica das relações de poder assimétricas e não-redutíveis à influência e às imposições da administração colonial.

\section{REFERÊNCIAS BIBLIOGRÁFICAS}

Almeida, Antonio José de Miranda e [1805]

Almeida, Eduardo Freitas e 1858

Almeida, Venancio d' 1912

Arnold, David 1993
'Conta do physico mór sobre a vaccina'. Autor não identificado, 'Introducção da Vaccina em Goa', Archivo de Pharmacia e Sciencias Accessorias, $\mathrm{n}^{\circ}$ 14, fevereiro, pp. 22-4; no 15, março, pp. 43-5. 1865.

Relatorio do anno de 1857. Arquivo Histórico Ultramarino, serviço de saúde da Índia, sala 12, maço 1987.

'Theses da escola medica de Goa 1911 - Medicina popular. Praticas populares. A variola'. Boletim Geral de Medicina e Farmácia, no ${ }^{\circ}$ 1, 1912, pp. 171-8.

Colonizing the body: State medicine and epidemic disease in nineteenth-century India. Berkley, University of California Press. 
Balsemão, E.A.S.N.P. e [Secretário Geral]. 1881

Baxby, Derrick 1996

Chaloub, Sidney 1996

Dias, Miguel Caetano 1902

Fenner, Frank 1996

Garcez, Caetano

Francisco Pereira 1844

Governo Geral do Estado da Índia 1927

Governo Geral do Estado da Índia 1918

Grmek, Mirko D. 1996

Guimarães, José Maria Teixeira de $1885 a$

Guimarães, José Maria Teixeira de $1885 \mathrm{~b}$

Jaggi, O. P. 1980

Latour, Bruno 1993

Loundó, Ramacrisna P. 1917

MacLeod, Roy et al. (org.) 1988

Manderson, Lenore 1996

Melo, Indalêncio Froilano de 1917

Melo, Indalêncio Froilano de 1931

Meneses, Caetano F. X. de
'Governo do Estado da Índia $=1881=\mathrm{n}^{\mathrm{o}}$ 51'. Arquivo Histórico Ultramarino, Serviço de Saúde da Índia, sala 12, maço 1983.

'Edward Jenner et l'introduction du vaccin antivariolique'. Em Anne-Marie Moulin (org.). L'aventure de la vaccination, Paris, Fayard, pp. 106-14.

Cidade febril: cortiços e epidemias na corte imperial. São Paulo, Companhia das Letras.

Estado da India portugueza. Relatorio do Serviço de Saude Referido ao Anno de 1902. Arquivo Histórico Ultramarino, Serviço de Saúde da Índia, sala 12 , maço 1985.

'L'érradication de la variole: de la prophétie de Jenner'.

Em Anne-Marie moulin (org.), op. cit., pp. 115-21.

'[Portaria] no 249'. Boletim Official do Governo do Estado da India, $\mathrm{n}^{\mathrm{o}} 13,30$ de março, p. 3 .

'Diploma legislativo provincial no 261'. Boletim Oficial do Governo Geral do Estado da Índia, nº 22, 18 de março, pp. 299-300.

'Diploma legislativo no 23'. Boletim Oficial do Governo do Estado da Índia, no 51,26 de junho, p. 601.

'Les premières étapes de la vaccination: mythe et histoire'.

Em Anne-Marie Moulin (org.), op. cit., pp. 41-56.

'[Portaria] no 310'. Boletim Official do Governo do Estado da India, no 138,30 de junho.

'Ex. ${ }^{\text {mo }}$ Sr. Redactor principal do Ultramar...'.

Boletim Official do Governo do Estado da India, no 98, 7 de maio, p. 391.

History of science, technology and medicine in India, Western medicine in India: social impact. vol. 15, Deli, Lucknow/Atma Ram \& Sons.

The pasteurization of France.

Cambridge/Londres, Harvard University Press.

'Vacinação antivariólica em Pernêm'.

Estado da Índia. Boletim Sanitário, vol. II, nº 6, junho, pp. 270-1.

Disease, medicine, and Empire: perspectives on Western medicine and the experience of european expansion. Londres/Nova York, Routledge.

Sickness and the State: health and illness in colonial Malaya, 1870-1940. Cambridge, Cambridge University Press.

'Varíola e vaccina na Índia Portuguesa'. Serviço de Saúde da Índia. $1^{a}$ Conferência Sanitária. Em comemoração do 72. aniversário da Escola Médico-Cirurgica de Nova Goa (1-12-1914 a 6-12-1914), vol. I.

Nova Goa,Imprensa Nacional, pp. 1-19.

Le service de santé à l'Inde portugaise.

Nova Goa, Imprensa Nacional.

'Relatório sobre a varíola e o serviço de vacina na aldeia Surla'.

Estado da Índia. Boletim Sanitário, vol. II, n⿳0 10, outubro de 1917, pp. 434-5. 
Moulin, Anne-Marie $1996 a$

Moulin, Anne-Marie 1996b

Oliveira, José António d’ 1853

Ribeiro, Florêncio Mariano

1917

Roberto, Antonio

Gomes (redator) 1864-1871

Roberto, Antonio

Gomes

1868

Santana, António

Ribeiro de

1918

Silva, Francisco António Wolfango da

1916

Silva, Francisco António

Wolfango da

Torrie, João Stuart da Fonseca 1884

Torrie, João Stuart da Fonseca

1883

Torrie, João Stuart da Fonseca 1881a

Torrie, João Stuart da Fonseca

1881b

O Ultramar

1884

Worboys, Michael 2000
'Introduction — L'aventure humaine de la vaccination'. Em Anne-Marie (org.), L'Aventure de la Vaccination, s. 1., Fayard, pp. 11-37.

'La métaphore vaccine'. Em Anne-Marie (org.), L'aventure humaine de la vaccination, s. 1., Fayard, pp. 125-42.

Relatorio do estado das Repartições de Saude do Estado da India. Arquivo Histórico Ultramarino, Serviço de Saúde da Índia, sala 12, maço 1987.

'[Relatórios mensais] Delegacia de Pernêm', Estado da Índia. Boletim Sanitário, vol. II, nำ 3, março, pp. 151-4.

Archivo de Pharmacia e Sciencias Accessorias da India Portugueza.

Nova Goa, Imprensa Nacional.

'Hygiene. Vaccina e revaccinação'.

Archivo de Pharmacia da India Portugueza, $\mathrm{n}^{\mathrm{o}}$ 56, ano 5, agosto, pp. 90-1.

[Relatório da delegacia de saúde das Ilhas], Estado da Índia.

Boletim Sanitário, vol. III, nํㅡ IV, abril.

'A profilaxia da varíola'. Estado da Índia.

Boletim Sanitário, vol. I, n⿳ำ 4, dezembro, pp. 102-3.

Relatório do Serviço de Saúde do Estado da Índia

(Novembro de 1917 a Junho de 1919).

Nova Goa, Imprensa Nacional.

'Copia - no 57'. Boletim Official do Governo do Estado da India, no 160, 22 de julho, pp. 639-40.

[Dados Physiologicos — Estado da India]. Estatistica medica dos Hospitaes das provincias Ultramarinas com referencia ao anno de 1879 e differentes mappas geraes para o estudo do clima e das doenças das mesmas Províncias. Lisboa, Imprensa Nacional, p. 147.

'Repartição do Serviço de Saúde do Estado da Índia, no 30'.

Arquivo Histórico Ultramarino, Serviço de Saúde da Índia, sala 12, maço 1983.

'Repartição do Serviço de Saúde do Estado da Índia — Numero 37'.

Arquivo Histórico Ultramarino, Serviço de Saúde da Índia, sala 12, maço1983.

$\mathrm{n}^{\mathrm{o}}$ 1293, 10 de janeiro de 1884; nº 1299, 21 de fevereiro.

Spreading germs: disease theories and medical practice in Britain, 1865-1900. Cambridge, Cambridge University Press.

Recebido para publicação em setembro de 2003.

Aprovado para publicação em março de 2004. 